International Research Journal of Engineering, IT \& Scientific Research
Available online at https://sloap.org/journals/index.php/irjeis/
Vol. 6 No. 2, March 2020, pages: $24-31$
ISSN: 2454-2261
https://doi.org/10.21744/irjeis.v6n2.861

\title{
Assessing Depth of Optimization Digital Samsat Program (E-Samsat) in Bali Province
}

\author{
Komang Widya Nayaka ${ }^{a}$ \\ Gede Sri Darma ${ }^{b}$
}

Article history:

Submitted: 09 November 2019

Revised: 18 December 2019

Accepted: 31 January 2020

\section{Keywords:}

digital technology;

samsat digital;

Vehicle Tax;

Badung regency;

good governance;

\begin{abstract}
This research describes the optimization of the Samsat digital program which has been tested in seven provinces in Indonesia, one of which is in the Province of Bali, Badung Regency. Digital Samsat hereinafter referred to as e-Samsat (Samsat electronics). The launch of the Samsat digital program is aimed at increasing the ease of paying motor vehicle tax for taxpayers. The implementation of the Samsat digital program is a form of information technology innovation in government programs in the industrial revolution 4.0 era. The application of this program is also to realize e-government and good governance. The purpose of this study was to determine the implementation of digital Samsat in the community and to determine the factors that influence the Samsat digital program. This research is a qualitative study conducted at the office of UPT Bapenda in Badung Regency (Samsat Office, Mengwi). The sampling technique for selecting informants in this study used a purposive sampling method. The instrument used in this study was using structured interviews, direct observation at the research location, and using supporting documents in the form of books and previous research about the same field study with this research. To test the validity of the data in this research used one of the methods, it was a triangulation of research data through checking on various sources to get saturated research data. The result showed that the implementation of the Samsat digital program in the community of Badung Regency the majority of users were satisfied and felt helped by the presence of the Samsat digital program that was launched. In its application in the field, there are many system components that must be updated to make it easier for taxpayers to use digital Samsat one of which is so that the entire process of digital equations becomes a fully online system.
\end{abstract}

International research journal of engineering, IT \& scientific research (C) 2020. This is an open access article under the CC BY-NC-ND license (https://creativecommons.org/licenses/by-nc-nd/4.0/).

\section{Corresponding author:}

Komang Widya Nayaka,

Undiknas Graduate School, Denpasar, Indonesia.

Email address: komangnayaka@gmail.com

${ }^{a}$ Undiknas Graduate School, Denpasar, Indonesia

${ }^{\mathrm{b}}$ Undiknas Graduate School, Denpasar, Indonesia 


\section{Introduction}

The era of industrial revolution 4.0 is an era in which all lines of life experience rapid development towards automation and digitalization which are marked by the importance of technological development. In this era the speed of information exchange is very easy, the existence of the internet (internet of things) is almost found in all lines of life. In addition, due to these developments also have an impact on increasingly complex human needs. One of the impacts of increasing human needs in this era is the increasing need for transportation. From year to year, the number of vehicles is always increasing as human mobility is advancing. On one hand, this has led to congestion, but on the other hand taxes on motor vehicles have also increased.

The increasing number of vehicles that are in line with the payment of high tax exams has not been able to align with the quality of service in the payment to date. The long waiting time (queuing) problem is a complicated problem for tax service officers. Samsat office as a manifestation of the Regional Revenue Agency which is the main guard for vehicle owners to fulfill their obligations. Various demands for improving service quality have been complained by the public at the Samsat office. Vehicle owners are required to pay taxes on time, but on the other hand, problems related to the length of the queue and the complicated payment procedures make people reluctant to go to the Samsat office.

In the midst of the current technological development, the community also expects the government, especially the Samsat motor vehicle payment service (Samsat), to adopt technological advancements to facilitate tax payment transactions. To that end, the government launched a digital-based Samsat payment program called Digital Samsat (e-Samsat). The presence of e-Samsat is expected to be a solution in optimizing tax revenue on motor vehicles and overcoming all obstacles and complaints in conventional tax payments.

E-Samsat Innovation shortens the work process of the administration team in the Samsat Joint Office. People only need to use the internet to register on the online Samsat page, then payment can be made at an ATM machine by entering the billing code or the privacy account code obtained. Digital or online samsat services can be accessed for 7 days 24 hours unless there is an error system or damage to the online system network. Pros and cons of applying samsat online occur in many fields, one of them is in Badung Regency. The obstacle faced by the public is regarding the payment process through e-Samsat, the existence of special codes included in the payment process confuses some people. Lack of socialization and unavailability of brochure instructions for digital payments at ATMs makes people not clearly understand how to pay for digital samsat, especially to people who lack knowledge of information and communication.

The e-Samsat program aims to realize good governance. The implementation of good governance is an effort made by providing good services to the community or commonly referred to as reforms to public services. Public service is a series of government activities or public bureaucracy in carrying out its obligations to meet the needs of the community (Dwiyanto, 2008). However, due to lack of socialization and education to the community can be an obstacle in the field.

So far the detailed evaluation and research related to the quality of Samsat digital services, especially in the Badung Region have not been effective. Therefore, the authors strive to conduct research related to the depth of optimization of the Samsat digital program. The purpose of this study was to determine the implementation of the Samsat digital program (e-Samsat) in realizing good governance in the community of Badung Regency.

\section{Literature review}

\section{Legal Basis for Taxes and Local Taxes}

Law of the Republic of Indonesia Number 28 the Year 2007 regarding General Provisions and Tax Procedures Article 1 Paragraph 1 describes taxes as a mandatory contribution form that must be fulfilled by a citizen because this is forced because the results are used fully for the prosperity of the people. There are two tax components, namely the central tax and the regional tax in accordance with their collection authority. One example of a regional tax that can increase regional income is the Motor Vehicle Tax (PKB). Law No. 28/2009 defines the PKB tax on motor vehicle ownership. PKB is expected to be able to support the increase in Regional Original Revenue (PAD).

Nayaka, K. W., \& Darma, G. S. (2020). Assessing depth of optimization digital samsat program (e-samsat) in Bali province. International Research Journal of Engineering, IT \& Scientific Research, 6(2), 24-31. https://doi.org/10.21744/irjeis.v6n2.861. 
Tax Reform

Ott et al. (2001) in Nasucha (2004), the reformation of the double carry out two main tasks namely: achieving high tax revenue effectiveness I which is also supported by efficiency which is also going well. The government as a regulator is expected to be able to create a high pattern of compliance for the people in fulfilling their obligations. This is the meaning of the word "effective". Meanwhile, efficiency implies that in the activities of tax payment the government is able to minimize administrative costs to a minimum. Extension reform means a series of policy and regulatory formulation activities to realize continuous tax revenue (tax revenue continuity). This tax collection is a set of provincial government authorities and forms part of the provincial tax.

\section{Theory of Diffusion of Innovations}

Everett M. Rogers quoted in Elvinaro \& Lukiati (2004), defines that diffusion theory is the process of delivering innovation through certain media. The diffusion of innovation explains how the magnitude of the role of a communicator who has mass information access can affect other individuals. There are several aspects that influence the decision making of innovation diffusion theory, namely:

The initial condition is the condition of a social system before adopting an innovation (Firdaus \& Wasilah, 2012). The initial conditions include the initial situation, needs and problems, innovation, and social systems.

According to Rogers (2010), explains that there are five aspects that influence the decision making of innovation diffusion theory, namely:

Knowledge. In this aspect, individuals do not yet have information about new innovations. The characteristics that influence this aspect are socioeconomic characteristics, individual variables (consisting of intelligence and attitudes towards change), characteristics of communication behavior (influenced by factors of participation and factors of contact with agents of change).

Persuasion is that individuals become interested in innovation and begin to actively participate in exploring the innovation. According to Rogers (2010), the characteristics of innovation that affect aspects of persuasion are relative advantages, compatibility, complexity, experiments, and finally, observational characteristics (the level of innovation results seen by others).

Decisions are on the aspect of individuals taking the concept of innovation, weighing the advantages and disadvantages of using innovation, and making an innovation-related decision. Decisions taken are adoption (innovation as a whole is put into action), rejection (the decision not to adopt innovation).

Implementation is in this aspect began to give a role to the individual in the innovation that was formed in accordance with the capacity and capabilities that are adapted to the current situation. The role of individuals is vital in the context of seeking and obtaining information in determining the usefulness of these innovations. Confirmation is the process after a decision is taken where an individual will seek justification for the decision taken.

According to Alexander (2010), there are several perspectives that cause the failure of innovation, namely strategy perspective (the occurrence of a failure in adopting innovation is something that cannot be denied, but if failure can be managed well it will be able to give a good impact as well. Technology perspective (innovation failure in innovation perspective in the perspective of technology can be caused by human problems, technical problems, or a combination of humans and the equipment used (technical).

\section{E-Government and Electronic Samsat (Digital Samsat)}

Indrajit \& Djokopranoto (2006), describes e-government as a form of utilizing technology (internet) in supporting government activities (bureaucracy) in providing quality public service quality. Lee (2009) states that the purpose of e-government is the effective delivery of public services to the public. E-Samsat (electronic-samsat) or digital form of technology-based PKB payment services is a tangible manifestation of the government's commitment to realize technology-based governance.

E-Samsat is a technology-based PKB payment system that can be done through a variety of registered banking services and in cooperation with the government ranging from ATMs, mobile or internet banking (Melaning \& Giantari, 2019; Yoga et al., 2019). To be able to use e-Samsat services, the vehicle owner's identification number (KTP) registered on the Samsat server must be the same as that listed on the bank account. Approximately 7 (seven) regions have adopted e-Samsat, starting from areas on the island of Java, namely: Jakarta, Banten, West Java, Central Java, Yogyakarta, East Java, and also the Province of Bali. 
Samsat online provides quality data and information that is more valid and up-to-date so that the achievement of the realization of tax revenue of all Regional Tax Services UPT (PPD) can be known in real-time. For taxpayers, the online Samsat service provides ease of PKB payment, because taxpayers can pay at any time anywhere so that they are free from long queue problems and avoid late payments.

\section{Good governance}

Good governance is defined as the overall management order of all sectors, both government and private, properly and correctly. Ulum \& Sofyani (2016), explain that good governance covers all aspects of both legal and legal aspects, social and political economy. Good governance is closely related to the procedures or procedures and mechanisms for the implementation of all elements of power both executive, legislative and judiciary. The characteristics of good governance according to UNDP (Arifin Tahir, 2014), are as follows namely participation, rule of law, openness, responsiveness, consensus-oriented, equality, effectiveness and efficiency, accountability and finally, is a strategic vision.

\section{Framework}

The framework of this research can be illustrated in Figure 1. The industrial revolution 4.0 had a major impact on every aspect of individual life, one of which was the President of the Republic of Indonesia launched a new breakthrough making Indonesia 4.0. This is a form of government commitment in preparing to face challenges in the industrial revolution era 4.0. Regulation of the Minister of Administrative Reform and Bureaucratic Reform of the Republic of Indonesia (PermenPAN \& RB) No. 30 of 2014 concerning the acceleration of improving the quality of public services, considers it very important for the government to create a series of public service innovations. This was then followed up with various policies and programs of public service innovation based on information technology (online system), one of which was an online vehicle tax payment program called E-Samsat. The onlinebased tax payment program in Badung Regency is regulated in the Local Regulation of Badung Number 2 of 2016 concerning the Local Tax Online System. E Samsat is part of an online-based PKB payment system. For this reason, researchers are interested in conducting a research study with the title: Assessing the Depth of Optimization of the Digital Samsat Program. This research was conducted at the Integrated Services Unit (UPT) of the Samsat Mengwi Office, Badung Regency. The research is intended to examine the implementation of Digital Samsat (E-Samsat) public service innovation in realizing good governance that contains principles of governance that are efficient, effective, transparent, openly competitive, fair, and accountable.

1. Revolusi Industri 4.0

2. Pemerintah Republik Indonesia Meluncurkan Program "Making Indonesia 4.0"

3. Peraturan Menteri Pendayagunaan Aparatur Negara dan Reformasi Birokrasi Republik Indonesia Nomor 30 Tahun 2014

4. Peraturan Daerah Kabupaten Badung Nomor 2 Tahun 2016 Tentang Sistem Online Pajak Daerah

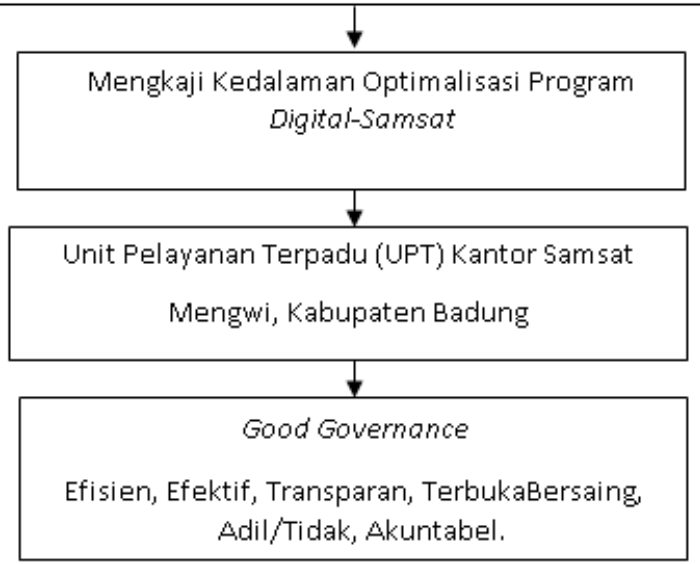

Figure 1. Research Framework

Nayaka, K. W., \& Darma, G. S. (2020). Assessing depth of optimization digital samsat program (e-samsat) in Bali province. International Research Journal of Engineering, IT \& Scientific Research, 6(2), 24-31. https://doi.org/10.21744/irjeis.v6n2.861. 


\section{Materials and Methods}

Badung Regency, especially in the UPT Bapenda office in Badung Regency (Samsat Mengwi Office), was chosen as the location of this research. The type of research data is a type of qualitative data. Qualitative data is descriptive data or narratives in the form of information needed in research, qualitative data is obtained through various types of data collection such as interviews, observations, and documentation. Data sources are secondary and primary.

Data on the number of bureaucratic officers assigned to the UPT of the Samsat Mengwi Office, Badung Regency and the people who make vehicle tax payments (Samsat) at the Mengwi Samsat Office, Badung Regency is the primary data on this research. Meanwhile, secondary data sources in this research are about research objects and are used by researchers in the analysis of documents, Presidential Instruction, Presidential Regulations, Legislation and books deemed relevant to this research.

The population and sample in the study used a purposive sampling technique, where the researcher will select an informant or sample based on the specific criteria that the author sets. The criteria set forth are as follows: firstly having the authority to provide information in implementing the e-Samsat program, having at least one (1) year work experience, having experience of having used an online tax payment system (E-Samsat), people who use the ESamsat program Samsat in paying vehicle taxes.

Data collection techniques that use the method of observation, and documentation on the research object. In this study validity checking techniques are used through triangulation of data through sources starting from time, interviews, observations, and documentation. Finally is to use reference materials that support or support the data that has been found. The data analysis technique used in this study is data reduction, through data presentation, through data verification. The purpose of conducting the data analysis process is to get the final data to be written in the report. The raw data obtained is then processed, discussed, and interpreted to be written in the report.

\section{Results and Discussions}

Based on the analysis of the data it was found that after a year of launching and implementing e-Samsat it has not shown a significant impact on increasing revenue on motor vehicle tax (PKB) or does not indicate the ease of administration of taxpayers. This is reinforced by the lack of e-Samsat users, which is only $0.9 \%$ of the total motor vehicle taxpayers. This is reinforced and can still be understood because it is still in the initial stages of implementation and improvement in various ways. According to information submitted by the Head of the UPTD Services Section, Samsat Mengwi, there were around 6000 people registered as e-samsat users in Badung Regency.

The inhibiting factors of the implementation of e-Samsat are first, e-Samsat is not yet a fully online system. This is because in practice after the taxpayers make the PKB bill transfer, they are required to come back to the Samsat office to get the STNK validation. This causes taxpayers to feel that there is no significant difference between conventional SAMSAT and e-Samsat because in the end they are obliged to return to SAMSAT Office to get STNK validation. To overcome these obstacles the Badung Regency Government plans to imitate the East Java Regency Government by providing an STNK printing press so that it does not need to go to the SAMSAT office again for authorization.

Another inhibiting factor encountered in the field is the lack of socialization related to the implementation of the e-Samsat program to the public. Based on the results of the interview it was found that the community as e-Samsat users said that they felt helped and supported the e-Samsat program conducted by the government. This is in line with the theory of innovation diffusion wherein the initial conditions of the community's knowledge of the presence of e-social security are still very low and the community tends not to know about this program, to various program socialization efforts and finally, the community begins to choose to use this program. Increased public knowledge is low in the initial conditions until the decision to adopt e-Samsat even though the level of use has not been significant shows the relevance of the theory of innovation diffusion in the implementation of e-Samsat in UPT.PPRD Samsat Badung.

\section{Conclusion}

Based on the results of the research and discussion, it can be concluded that the Samsat digital program (e-Samsat) is one of the applications of e-government in order to realize good governance in the Badung Regency Government 
related to the optimization of public services, especially related to vehicle tax. The results showed that the implementation of e-Samsat has not been able to provide significant benefits, both in increasing PKB revenues and direct benefits for taxpayers especially the direct benefits in the form of accessibility and ease of PKB payments so that the implementation of this program has not been able to support government efforts in realizing good governance good (good governance).

From the research results obtained supporting factors for the implementation of Digital Samsat (E-Samsat) in the UPTD Samsat Mengwi in Badung Regency include participation in the digitalization era, ease in getting information on the amount of PKB payments, time efficiency and speed of payment, E-Samsat's ability to minimize payment delays. There are also inhibiting factors of the e-Samsat program implemented, namely e-Samsat is not yet fully implemented with the full online system method, public knowledge about e-Samsat is relatively minimal, people still feel complicated with the e-Samsat payment flow, lack of program socialization to community, and the habit of using formal or informal intermediary services or (samsat brokers) which are still more favored by the general public taxpayers.

Suggestions that can be delivered in this research are related to the implementation of the e-Samsat program which is still not significant, so the government in collaboration with all relevant parties should conduct a comprehensive study in collaboration with independent institutions and expert teams to improve the quality of the eSamsat program so that it can become a solution in the realization of e-government and good governance. The related parties should further enhance the e-Samsat program so that it is more user-friendly with the taxpayer community, the more frequent the socialization to the community.

\section{Conflict of interest statement}

The authors declared that they have no competing interests.

Statement of authorship

The authors have a responsibility for the conception and design of the study. The authors have approved the final article.

\section{Acknowledgments}

We are grateful to two anonymous reviewers for their valuable comments on the earlier version of this paper.

Nayaka, K. W., \& Darma, G. S. (2020). Assessing depth of optimization digital samsat program (e-samsat) in Bali province. International Research Journal of Engineering, IT \& Scientific Research, 6(2), 24-31. https://doi.org/10.21744/irjeis.v6n2.861. 


\section{References}

Alexander, M. (2010). Infusion nursing: An evidence-based approach. Saunders/Elsevier.

Arifin Tahir, M. S. (2014). Kebijakan publik dan transparansi penyelenggaraan pemerintahan daerah.

Bappenas, 2008, Evaluasi 3 Tahun Pelaksanaan RJJMN 2004-2009 “Bersama Menata Perubahan”. Kementerian Negara Perencanaan Pembangunan Nasional/Bappenas, Jakarta.

Elvinaro, A., \& Lukiati, K. (2004). Komunikasi Massa Suatu Pengantar. Bandung: Simbiosa Rekatama Media.

Firdaus, A., \& Wasilah, A. (2012). Akuntansi Biaya.

Ihyaul, U., \& Sofyani, H. (2016). Akuntansi Sektor Publik, Aditya Media, Malang.

Indrajit, R. E., \& Djokopranoto, R. (2006). Manajemen perguruan tinggi modern. Andi.

Lee, R. (2009). Social capital and business and management: Setting a research agenda. International Journal of Management Reviews, 11(3), 247-273. https://doi.org/10.1111/j.1468-2370.2008.00244.x

Melaning, A., \& Giantari, I. (2019). Technology acceptance application model on internet banking service in BRI Bank Denpasar Indonesia. International Research Journal of Management, IT and Social Sciences, 6(4), 135146. https://doi.org/10.21744/irjmis.v6n4.667

Nasucha, C. (2004). Reformasi administrasi publik: teori dan praktik. Gramedia Widiasarana Indonesia (Grasindo).

Ott, H., Fortagh, J., Schlotterbeck, G., Grossmann, A., \& Zimmermann, C. (2001). Bose-Einstein condensation in a surface microtrap. Physical review letters, 87(23), 230401. https://doi.org/10.1103/PhysRevLett.87.230401

Peraturan Daerah Kabupaten Badung Nomor 2 Tahun 2016 Tentang Sistem Online Pajak Daerah.

Peraturan Menteri Pendayagunaan Aparatur Negara dan Reformasi Birokrasi Republik Indonesia Nomor 30 Tahun 2014 tentang Pedoman Inovasi Pelayanan Publik.

Permenpan dan Reformasi Birokrasi No. 30 Tahun 2014 Tentang Pedoman Inovasi Pelayanan Publik serta Kebutuhan Inovasi LAN.

Rahadian, A. H. (2008). Mewujudkan Good Governance Melalui Pelayanan Publik. Jakarta: Jurnal Transparansi, 1(2), 57-70.

Rogers, E. M. (2010). Diffusion of innovations. Simon and Schuster.

Surat Edaran tertanggal 28 Juni 1977 Nomor 16 Tahun 1977, tentang Pedoman/Pengurusan Pelaksanaan Sistem Administrasi Manunggal dibawah Satu Atap dalam pengeluaran Surat Nomor Kendaraan Bermotor (STNK), Pembayaran Pajak-pajak Kendaraan Bermotor (PKB/BBNKB) dan Sumbangan Wajib Dana Kecelakaan Lalu Lintas Jalan (SWDKLLJ).

Undang-Undang No. 28 Tahun 2007 tentang ketentuan umum dan tata cara perpajakan.

Undang-Undang No. 28 Tahun 2009 tentang 2009 tentang Pajak Daerah dan Retribusi Daerah.

Yoga, I. M. S., Korry, N. P. D. P., \& Yulianti, N. M. D. R. (2019). Information technology adoption on digital marketing communication channel. International Journal of Social Sciences and Humanities, 3(2), 95-104. https://doi.org/10.29332/ijssh.v3n2.297 


\section{Biography of Authors}

\begin{tabular}{|l|l||}
\hline Komang Widya Nayaka was Born in Same, Manufahi on 19 July 1995. Now He is 25 \\
years old, and now he still became a student in Undiknas Graduate Scholl especially in \\
magister public administrations programme. He became a Staff Assessment for library \\
development, documentation, and information in Mengwitani No.1 Elementary School \\
(SDN 1 Mengwitani), one of elementary school on Badung regency. \\
Email: komangnayaka@gmail.com
\end{tabular}

Nayaka, K. W., \& Darma, G. S. (2020). Assessing depth of optimization digital samsat program (e-samsat) in Bali province. International Research Journal of Engineering, IT \& Scientific Research, 6(2), 24-31. https://doi.org/10.21744/irjeis.v6n2.861. 